\title{
CAREFUL PLACE
}

\section{Matters of care built into the sustainable city district}

by Maria Eidenskog

In Vallastaden, a newly built city district in Sweden, place is carefully crafted to make it into a role model city district of the future. These "careful places" are built with care, but also require physical care, such as cleaning and gardening, as well as administrative care through paperwork and organizing. This article focuses on how thinking with care in the analysis of the planning for and living in Vallastaden can contribute to highlighting the complexities often made invisible in city planning and put what is marginalized at the centre. The article empirically studies how the planning of careful places is done in planning documents and builds on workshops with residents in Vallastaden. In the workshops, inhabitants of Vallastaden are asked to draw their own map of their city district, so called mental maps. These mental maps are discussed with regard to how place in Vallastaden enables care, is cared for, and what troubles they bring. Careful place has the power to create tensions in planning, which is handled by making some matters absent or translated into other matters of care. Likewise, careful place is enacted with multifold practices in the everyday life of the residents in Vallastaden, intertwining self-care, care for the environment as well as a caring space for sharing problems in virtual space. Staying with the troubles of careful place creates awareness of otherwise neglected matters, such as how socio-economic diversity is translated into diversity in housing, and through this approach turn to the ethico-politics of urban planning.

Keywords: Author: Licensing: 


\section{Place and care - an introduction}

In Linköping, Sweden, a small stream runs through a newly built city district called Vallastaden. Green infrastructure, decorated walking paths, and a bridge that is called "the outside living room" tells of carefully crafted places for people to enjoy. The place, however harmonious it might seem, has required sacrifices. While some now live their everyday lives enjoying the stream, others have had their lives completely changed to make this careful place come about. A large habitat of the endangered great crested newt' was found during the planning process for this city district. The habitat, with over 170 great crested newts, had to be moved to a location outside the city (Linköping University, 2013). Thus, the stream is a result of careful planning, but also a place of disruptive action, taking homes from some to make homes for others. Or in the words of Puig de la Bellacasa: "Care eschews easy categorization: a way of caring over here could kill over there" (Puig de la Bellacasa, 2011, p. 100).

Vallastaden is portrayed as a role model city district with its special focus on social sustainability. Furthermore, if Vallastaden is the role model city district for future city planning in Sweden, it becomes vital that we recognize what matters of care are enacted as important and what are left out in the process. This care may look very different in different situations. Care for the privacy of the great crested newts cannot co-exist with caring for the construction of new homes in Vallastaden. The politics of the careful places in Vallastaden are built on a web of matters of cares, some are made present and others necessarily must be absent (c.f. Law, 2004). The aim of this paper is to explore how thinking with care in the analysis of the planning for and living in Vallastaden can contribute to highlighting the complexities often made invisible and put what is marginalized at the centre. This will be done by teasing out what matters of care are made important and what are made absent by different actors and what frictions between matters of care are present in the making of careful place in Vallastaden. City planning has implications for the everyday life of all citizens, and in order to grasp the relationality and interactions between objects and practices of planning, the field of science and technology studies can be of service (c.f. Kurath et al., 2018; Aibar \& Bijker, 1997).

I use concepts inspired by Actor-Network Theory, such as enactments (Mol, 2002) and translations (Callon, 1984; Law, 2006), to make visible how different matters of care are enacted as part of making careful place. Thinking in terms of enactments instead of constructions allows us to avoid perspectivism, i.e. that the word is made up of different perspectives. Thinking in terms of enactments acknowledge that there are different versions of the world which could be separate, but also include different relations and can be interlaced ( $\mathrm{Mol}, 2002)$. When approaching the world as built up of different versions instead of constructions we turn to activities and practices that are "done" (Gad \& Jensen, 2010). Focusing on place as a part of enacting the worlds we live in, place comes in more than one, but less than many, versions. By in this way approaching space as multiple, research can open up for questions about how to balance ethical considerations and complex issues (Jensen \& Sandström, 2019). Furthermore, the enactment of worlds include a multifold of translations, that is, transformations of objects or actors by establishing connections through equivalence (Law, 2009). For example, the process of economization is a translation of worth into monetary value, by translating objects into numbers. It can also be a part of the attempts by some actors to impose themselves and their definition of a situation on others (Callon, 1984).

This article follows how social sustainability is translated into the built environment and the everyday life of the citizen and how careful place is enacted in practice both in the planning for a socially sustainable city district and in the everyday lives of the residents. By focusing on care in relation to place, both in planning and in everyday life, we can ask important questions, such as "for whom is the city built?", and "who cares for the city?", while still focusing on how the built environment enables the residents to engage with care. The need for studies on the relationship between place and care practices has been highlighted in research (Dyck, 2005; Dyck et al., 2005; Metzger, 2014) and this article connects to that discussion by introducing the concept of "careful place" in order to understand how place is enacted as practice and as politics in the making of Vallastaden. According to Metzger (2014), caring for place can be a way to engender a sensitivity towards the connection between care for both humans and other actors. This could be useful in order to sensitize us to care for more-thanhuman ecologies and create an awareness of our part in them (Metzger, 2014).

Puig de la Bellacasa describes care as: "[...] a manifold range of doings needed to create, hold together, and sustain life and continue its diverseness" (Puig de la Bellacasa, 2017, p. 70). Following this notion of care entails care as a necessity and condition, not as a normative prescription or moral obligation. Thinking with care about care comes with a set of understandings of the world and leads to new questions. In the words of Puig de la Bellacasa: "An account of a thing produced with and for care can indeed create divergence and conflict by criticizing the way an issue is assembled. It can produce visions that 'cut' differently the shape of a thing [...]" (Puig de la Bellacasa, 2011, p. 96). Thinking with care means that phenomena are viewed together with their relations to humans,

\footnotetext{
1 The great crested newt is red listed by the International Union for Conservation of Nature and protected by laws in Sweden. Their habitats are threatened by changes in the landscape due to modern farming practices (Malmgren, 2011).
} 


\section{N}

NORDIC JOURNAL

of Science and Technology Studies

non-humans, their worlds, and the associated "doings". Thus, this approach requires the researcher to care for the cuts made through the chosen methodological practices and to foster a responsibility for the outcome of these cuts. The politics of care as suggested by Puig de la Bellacasa (2015, p. 707) are part of: "[...] a feminist politics that brings attention to ethico-political questions about such matters as who cares for whom and what forms of care are prioritized at the expense of others [...]". It highlights the ethico-political dimensions of the everyday through the focus on the doings required to sustain everyday life.

In addition, care has also been portrayed as a concept for understanding practices aimed at improvement with respect to the current situation (Heuts \& Mol, 2013) or caring for the maintenance of something (such as a farm, e.g. Harbers, 2010). Care done in practice can be analysed in form of tinkering, as a way to adapt, to be attentive to, and to compromise in order to care for (and about) things that matter ( $\mathrm{Mol}, 2002)$. Care as tinkering means to adapt with watchfulness and cannot be normalized (Denis \& Pontille, 2015). Thinking of care as tinkering steers the focus away from the traditional connection between care and the warm relationships between humans to a broader scope where the interweaving of technology and everyday practices is in focus (Mol et al., 2010).

The theoretical foundation in this research puts care for our living environment in centre as an ethico-political question which bring about decisions where some forms of care are prioritized over others. In studying the enactment of social sustainability in a role model city district, this approach requires us to turn to the ethicopolitical dimensions of the built environment and its consequences for everyday practices, their embodiment, situatedness and temporality. Focusing on the practices of care, the notion of tinkering will help me to study the ordering of different matters over others. Practices of care are always shot through with asymmetrical power relations (Martin et al., 2015). From this viewpoint, planning for a city district with the special aim of making it socially sustainable is a practice where care creates conditions for (some but not all) actors to thrive. There is a tinkering between different goals (such as infrastructures, logistics and recreations), political decisions and care for the people who will come to live within the city district. Therefore, care is not above criticism, since different care practices can lead to different, and sometimes unwanted, ethico-political outcomes. Care does not have to be gentle and affectionate; care can sometimes include killing (Law, 2010) and has a dark side to it (Martin et al., 2015). Working with care as trouble (Lindén, 2016) is one way to bring attention to the ethico-politics of care by staying with the tensions that care creates. Inspired by Metzger, I suggest an approach built on critical engagement by way of asking: "what can be done here? What can become here? And at what price?" (Metzger, 2014). Through these questions, we can understand the matters of care that are enacted or made absent in the planning of Vallastaden and the everyday life of the residents living there.

\section{Methodology}

The first part of this study focuses on the planning process and the documents used in the early stages of the process. That part is built on a document study of municipality documents that were used in the planning of the city district. It includes the "idea programme" which describes the vision behind Vallastaden, quality documents, various policy documents, urban planning documents, documents from an architecture competition in Vallastaden and criteria documents for the prospective clients who wanted to buy a plot of land in Vallastaden.

The documents were coded in Nvivo with initial coding structure (Saldana, 2009) and later coded thematically from themes discovered in the first coding phase. The aim of this empirical part is to show the tinkering behind the built environment that was constructed in Vallastaden. The documents show some of the practices applied during planning and provide perspectives on what Vallastaden should become and what values were envisioned in the buildings that today are part of the city district. In the analysis, I have asked how care is done, what matters of care are made visible in the texts, and what matters of care are made absent? The results from this process are presented in the first part of the results section.
The second part of the study is based on empirical data from five workshops with residents in Vallastaden. While the document study was used to trace how care for social sustainability was enacted in writing and policy, the workshops provided an interactive method for listening to the experiences of the residents. The workshops had between two and four participants and in total 15 residents took part in the study. At the time of the workshops, the participants had lived in Vallastaden between two and three years, were 20-45 years old and the majority owned their apartments. Seven of the respondents were women and eight were men. One workshop consisted only of students who lived in student housings. The participants were recruited from personal connections and a Facebook group about Vallastaden. Some of the participants were more involved in the shared activities in Vallastaden than the average resident. As the aim of the workshops was to understand how care is done and to study the care put into the engagements in Vallastaden, these respondents were an appropriate choice.

The workshops took place in the home of one of the participants for each workshop. The workshops took between 1.5 and 2 hours each and were recorded with a voice recorder. Two researchers were present; one researcher led the workshop while the other 


\section{$\$$}

NORDIC JOURNAL

of Science and Technology Studies

took notes. The workshop started with a discussion led by one of the two researchers present. After a short question session, the participants were asked to draw a map of their own Vallastaden. We asked them to think about what places they liked, which places mattered to them, places that they avoided and passages where they travelled or walked. This methodology is a way to create so called "mental maps" (Gould \& White, 2004) and create a more material connection between the discussions in the workshops and the environments in Vallastaden. By drawing their own version of a map, the participants created a link between space, places, and buildings, making visible relevant interrelations, sensory and emotional experiences (c.f. Osóch \& Czaplińska, 2019). The mental maps were discussed, and the researchers asked questions about how places were used and cared for. The mental maps together with the discussions provide both visual and narrative understanding of what matters of care the respondents valued or missed in Vallastaden. This method facilitates the collecting of narratives, associations and metaphors which carry specific contents and meanings in relation to place (Osóch \& Czaplińska, 2019). For this research project, the drawing of the maps was an important tool as part of the discussions concerning what the respondents felt about different places and how they used them. It created space for stories about care, through turning attention to the places which the respondents had feelings for, and it made visible connections between different geographical sites by how they were placed. The respondents pointed on the maps and related different places and paths to each other, sharing stories on how their lives revolved around places they found important. This enabled discussions about the interrelations between care and geographical space.

\section{Background}

There is a current boom in the construction industry in Sweden and there is a fear that environmental and cultural values will not be taken into consideration (Malmgren, 2011). Social dimensions of housing are also debated, for example in terms of homelessness, segregation, overcrowded flats, gentrification, inequality, low income filtering and social polarization (Hedin et al., 2012). In this context, much national attention was drawn to the high social sustainability ambitions in the new city district of Vallastaden, in Linköping. Vallastaden has the political aim of being a role model city district for future urban development, residential areas, and housing. Previous research on the early stages of planning has shown that several local stakeholders, such as the municipally owned energy and housing companies as well as privately owned building service companies, were mobilized in the development (Palm \& Wihlborg, 2013). The local council in Linköping also arranged activities to engage citizens and collect ideas about an ideal new neighbourhood. Citizens were invited to take part in visionary meetings in the early stages of planning Vallastaden and their views where documented in three shorter reports. These reports where used in the creation of a vision, including some guiding principles for Vallastaden. The vision was turned into a contest for the design of Vallastaden. The Stockholmbased architectural firm Okidoki won with their contribution called "Tegar" (Okidoki, 2020). Their idea was to sell small land allocations to a variety of actors to achieve a modern and diverse cityscape. This vision was put into practice during a short building process (most houses were built from 2013-2017) and in 2017 the city district was showcased in a large housing exhibition. The housing exhibition was the largest ever held in Sweden and had 75,000 visitors. About 1000 dwellings were built in five years by 40 actors (Vallastaden, 2019).

The keywords for Vallastaden are "dense, green and diverse" (Vallastaden, 2019). The area is divided into small plots of land that were sold to a large diversity of actors in accordance with a points system. Since the blocks are built on such small plots, one of the criticisms against Vallastaden is the lack of sunlight in some places due to the dense city planning. Green infrastructure, such as the small stream is the centre of Vallastaden, was important in the planning process. In addition to these smaller green areas, there is a large park with allotments for gardening and community areas in the outskirts of Vallastaden.

To be able to build a block in Vallastaden, the housing companies had to file an application where they showed how they fulfilled certain criteria that were set by the municipality's urban planning office. The criteria are described in a document that sets out a points system, which was used to decide who would be able to buy land in Vallastaden. The interested parties applied to purchase land allocations and the one with the highest points was given the opportunity to buy the area. For each criterion, the property developers could gain points that were summed up and compared with the competitors. There were four overall criteria: (1) Resource efficiency - the buildings need to meet measures for energy, management of resources etc. (for example, solar panels on the roof gave 1 extra point, solar panels on walls gave 2 points). (2) Architecture - the suggested building needs to be innovative and contribute to a diverse cityscape (if more architectural firms than required were engaged in the planning of a block, the land developers could receive up to six extra points). (3) Learning and creativity - the building projects can earn points for contributing to learning, including partnering with a university, which would give up to 2 points. (4) Social sustainability - including green infrastructures as well as criterion for rent control. The last section will be further investigated in the following sections. As we will see later in the paper, the criteria document for land allocation is an important step in the operationalizing of the urban planning. 


\section{Results \\ Tinkering in the planning of caring places}

Social sustainability was the focus of the vision for Vallastaden from the start. "People are building the city" is the trademark for the planning process, which is done through involvement of the citizens. In this section I will discuss the matters of care that are made visible, how they are cared for in planning, and how some matters become absent during the process. This part will focus on the documents from the planning process, including municipality planning documents, visionary documents from the architectural firm Okidoki as well as documents from meetings and workshops that involved citizens.

\section{Caring for the environment}

The great crested newt is a protected species and it is forbidden by law to move, kill or harm the newts (Malmgren, 2011). One of the largest nests of great crested newts in Sweden was discovered in the ponds where Vallastaden was supposed to be built during the planning stage. The newts require a high density of ponds to build habitats and reproduce. There is a growing lack of suitable environments for the great crested newt in Sweden and they have problems in moving from one location to another (Malmgren, 2011). An investigation into the situation for the newts was launched and in 2013 an application for exemption from the protection laws was accepted by the county administration. New ponds were built which exceeded the quality of the ponds in Vallastaden, both in size and in number.

The great crested newt took up a large section of the detailed development plan for Vallastaden, but it was not given a home there. The city district could not be built around the newts' ponds; the needs of the newts and the needs of the humans could not be reconciled. Building new homes for humans was enacted as a more pressing matter of care than the already existing home for the newts. Although the newts did not fit into the plan and were evicted, care was put into the making of a new home for them. Thus, the care for the newts' wellbeing was able to mobilize some efforts - building new ponds, but not moving the location of planned buildings.

The urban planners involved in the making of the detailed development plan for Vallastaden had to decide on what actions were viable and attractive for citizens who wanted to live in Vallastaden. By choosing the design of the neighbourhood, they also shaped the citizens that would come to live there. Sometimes, the urban planners and the citizens involved in the planning disagreed, which led to a tinkering with words and meanings. One discussion raised by the citizens is that they want Vallastaden to be car free. This is something that seems to be important since several citizens raise this issue in different meetings. However, the city planners do not think a totally car free city district is realistic. In the documents from the workshops with citizens, car free zones are seen as important, even though the urban planners respond to the suggestions from the citizens with some caution. In the detailed development plan, which was made public three years later, only cars with special authorization are allowed on one of the main roads in Vallastaden and the speed limit is set at $20 \mathrm{~km} / \mathrm{h}$. The other main road through Vallastaden is almost made absent in the documents. This road is open to all traffic and connects Vallastaden with nearby university buildings and other city districts. The tension between the citizens' request for a car free city and the care for easy accessibility by car had to be made absent to create the urban planners' vision of Vallastaden.

Instead of removing the cars, they become a tool in the vision and enable one form of care - that for the environment enacted through electric cars. Cars are "care enablers" (Eidenskog, 2015) and the intertwining of cars in the vision of the future city district comes with a set of political decisions. Multi-storey car parks are built on the outskirts of the city district which are meant to allow residents to use cars but not to take them all the way to their homes. The car parks have solar panels on the walls and beehives on the roof. Furthermore, all residents in Vallastaden must be part of a carpool as a part of a sustainability effort. Seemingly paradoxically, the car parks are through these efforts enacted as a caring place for the environment. Moreover, if the car is an electric car it is put on display by the stream since not all cars are enacted as environmental hazards. Charging stations for electric cars are put up along the walking path, thus making the cars very much a part of Vallastaden. The idea of Vallastaden as a car-free zone is turned into a zone for some cars, but not all. Some cars are cared for, made a place for and used to show care for the ecological environment. The room made for electric cars is justified with statements like this from the municipality's idea document: "Make room for the transport system of the future!". A careful place is in this setting not free from cars, which the citizens wanted; cars are instead used as a tool to care for other matters. The car holds a strong position in Swedish planning tradition (Lundin, 2008) and it was therefore in the planning process difficult to make cars fully absent in Vallastaden. With the tinkering done by the planners through a series of translations cars changed from an environmental hazard and a disruptive element in a peoplefriendly neighbourhood to a tool to show care for the environment and the future transport system.

\section{Diversity as built environment}

In the meetings with the citizens, social sustainability is characterized by diversity, an active city, beautiful public places, and meeting places. In the documents from the meetings with the citizens, diversity of people from different backgrounds was important. Vallastaden was envisioned to be a place where you could meet people you otherwise would not meet and learn from 


\section{$\$$}

NORDIC JOURNAL

of Science and Technology Studies

each other. However, throughout the documents, there is a shift in the interpretation of what diversity has come to be. To be able to create conditions for diversity in Vallastaden, there had to be a broad socio-demographic profile in the area. It soon became clear that the price of land in Vallastaden would be higher than average prices in Linköping, making it hard to build cheaper rental apartments.

To be able to build properties in Vallastaden, all property developers had to apply to buy land. Their applications where measured against the criteria document which measured ecological footprint, citizens involvement, creativity, and social sustainability. Social sustainability is operationalized in the criteria document for land allocation in ways which became important for the design of the city district, for example through themes where the property developer can earn points. If the building had some kind of green area, such as a winter garden, that gave up to 9 points. If presumed residents where involved in the planning of the building this also gained the property developers up to four points. There is no motivation behind the different numbers, but all the factors can be linked to discussions in previous published planning documents, such as the idea programme. The point system used in the document builds on an understanding of numbers as a means to homogenize or to order heterogeneities (c.f. Moser \& Law, 2006). By attaching numbers to winter gardens and solar panels they are weighed against each other and enacted as equal points on a linear scale. Social sustainability is acknowledged to be hard to quantify (Baffoe \& Mutisya, 2015; Arnett, 2017) but in the planning process for Vallastaden, social sustainability is clearly defined by the criteria document for land allotment.

One important aspect under the social sustainability heading was "Different forms of housing", which in practice meant that houses which had different sizes of apartment were given more points than properties with only one or two apartment sizes. For rental apartments and multi-generational housing, the property owner received up to four points. In another municipality document on the vision for Vallastaden, the importance of different sizes of housing is described as an investment in diversity. This was a way to create a diverse cityscape and allow for different sizes of family constellations to find a home in Vallastaden. The matters of care that are made present are concerned with the variety in the forms of housing and an availability of choice. Diversity was in this setting translated into the position of walls and provided a way to care for a certain form of diversity in sizes - both in apartment and in family arrangements.

The visions in the documents portray a future where the concept of "family" is flexible. In the idea programme, produced by the municipality by collecting the experiences from citizen engagement workshops, this is mentioned as an important goal: "Establish a home that can change with life!". Families are expected to change more in the future and sometimes the kids will be at home, other weeks only one or two parents will be at home. This calls for a flexible living arrangement and shared space that could be utilized when the family is temporally larger in size. The possibility of having multi-generational housing is also brought forward as something that could be of interest in Vallastaden, both in early planning documents from citizen workshops and later in the land allocation criteria document. The notion of flexibility connects to space efficiency and the documents state that not everyone needs their own apartment in the future city.

Flexibility is enacted as a matter that can bring about freedom for the residents and as a concept flexibility is presented as free from criticism. Enacting flexibility as a matter of care for the future city district is multifold and is both a tool to save space and energy, but also to question the norm of today's living arrangement and be open to new lifestyles. Spatial flexibility could be argued to complement a socio-demographic flexibility in the city to support a variety of different lifestyles (Bouzarovski, 2015). This openness, and its enactments in the built environment, is created with care for the people living outside the traditional norms for a family or family life. If there were tensions in the discussions about the flexible city district of the future in the discussions, these were not made present in the documents. The lack of tensions makes flexibility as a concept interesting as it easily travels through the planning process. Even so, research has also shown that residents avoid homes in which the flexibility is built into the buildings in the form of movable walls and beds (Till \& Schneider, 2005). Thus, flexibility as part of a social sustainability agenda could benefit from being opened up for further discussion.

Another way diversity was enacted in the criteria document was through business facilities. If a building facilitated a business which hired people who had "fallen outside the labour market" (examples provided were older workers who had trouble finding new employment, immigrants or people recovering from addiction), up to 1 point was awarded. This criterion is connected to the discussion from the early document from the meetings with citizens. The citizens asked for a diversity of people from different backgrounds. Even though it travelled successfully from the early phase of the planning process, with its one point it is equal to the effort of putting solar panels on your roof, but less important than solar panels on the walls of buildings. The points system very clearly shows that the diversity agenda became one of flexible housing rather than a city of people with diverse backgrounds. The care by numbers enacted in the document has important consequences for the built environment and for whom the city is built.

There is another opportunity to contribute to a diverse population, namely through the last criterion which is named "cheap rental apartments". The aim of this criterion was to create a diverse socio-economic demography in Vallastaden. If the rents were 
less than SEK 1250 per square meter per year, ${ }^{2}$ up to 6 points could be gained. However, no one lived up to this criteria during the first round of land allocations. In the second round of land allocations, the criteria were changed to fit the rents that were seen as reasonable in the area. The new criterion was set at SEK 1600 per square metre per year and for the land allocations in 2019, two landlords applied for points for low rents. "It is still a high rent. But it is $10-20 \%$ lower than the others, so it is positive" the chair of the planning committee in Linköping, Elias Aguirre, told the local newspaper (Alvin, 2018). As we will see in the next part of this paper, Vallastaden is often seen as a middle/high income area due to its high rents. Care is put into action in the criteria document and from this document we can see how some matters of care were translated and operationalized using a number system. Diversity in building design was a successful criterion but cheap rental apartments failed to change the city development. The planners had to tinker with this criterion in order to make it relevant. The care for a diverse city inscribed in the criteria did not move walls like the diversity of apartment sizes could. Thus, it is harder to activate care for a socio-economic demography than for non-traditional family constellations. Care for this version of diversity makes other versions absent and this process calls to mind the concept of the "dark side of care" (Martin et al., 2015). Care in this understanding is an affectively charged and selective mode of attention. By analyzing care as "critical care" we can expose the dark side of care (Martin et al., 2015). This analytical stance draws attention to how diversity is cared for in forms of housing but not in a care for people from different backgrounds. The diversity in forms of income is made absent and replaced with other enactments of diversity that are easier to care for in the costly new built city district. Some people are therefore excluded in the planning for Vallastaden. The critical care analysis draws the ethico-political decision of the urban planners to the front by paying attention to the things made absent.

\section{Meeting places as careful place}

Meeting places are brought up as important tools to create social sustainability. Meeting new people with different experiences was important from the beginning of the planning process and is emphasized by both citizens and urban planners. Meeting places and shared space are central to the social sustainability agenda in the planning for Vallastaden and are also made present in the built environment. All apartment blocks in Vallastaden are connected to one of the seven so called "Felleshus". The Felleshus is meant to be a meeting place and a place to create relationships. Residents in neighbourhoods have responsibility for organizing activities and for the maintenance of the shared Felleshus buildings. These Felleshus have space for gardening and an overnight apartment which the residents can rent. These buildings require tinkering but lack a predefined organizational structure. The aim is to let the residents themselves organize and find their own use for the shared space. The Felleshus is planned as a careful place, which requires care in maintenance but also facilitates care through creating connections between people. Meeting your neighbours in the Felleshus can foster caring relationships over time. Likewise, there are other meeting places that are made important in the planning documents. Some of the activities that we usually do in our own home were distributed to shared space in Vallastaden, for example the residents share space in the "Paradiset" park instead of having their own gardens.

A place built and planned with care can provide a place where care can also be practised. In Paradiset people can gather for a barbecue, stroll along the paths, or grow their own vegetables. Caring for vegetables and caring for family or friends by spending time together are some of the practices that are encouraged according to the planning documents. The place is an enactment of values that the planners envision people want in their lives, such as space for togetherness, green areas, and a place to experience nature.

Social sustainability, both in the policy documents and in the criteria document, is most often enacted through a focus on meeting places. This form of space is a way to create connections and interdependencies as part of everyday activities, something that Puig de la Bellacasa (2012) mentions as part of an ethicopolitical dimension of care. Creating meeting places is thus a practice that can create careful place. Of course, the opposite might also happen - that meeting places create space for tension or hardship. Furthermore, meeting places are, in the documents, argued to be a way to create inclusion and connections in Vallastaden. However, the meetings are only accessible for and designed for some, and always from a human experience perspective. Metzger (2016) argues that we need a broader repertoire of methods to facilitate inclusion of the will and desires of other-than-human actors. The meeting places in the park Paradiset are designed to encourage meetings between people through common facilities as well as between people and nature through gardening. Nature is made present but in a systematic fashion in straight lines and through fenced-in areas. The carefully crafted park becomes a place where humans come to meet and to order nature. Thus, staying with the troubles in the planning for meeting places shows that the matters of care which are made present in the built environment recreates a governing of nature rather than a more open inclusion of a heterogenic set of actors. Where meeting places are enacted as a part of a social sustainability agenda, it is necessary to ask who are supposed to meet whom and on what conditions?

2 The average rent for all types of apartments in Linköping is about SEK 1200 per square meter per year. 


\section{Meeting the residents}

The planning documents for Vallastaden showed the tinkering done over time through planning decisions. In this section we will get a glimpse of the everyday life of Vallastaden through the residents' perspectives. This will show how the built environment creates engagement, attachment, and tension, and that these contrast with the matters of care brought forward in the planning documents.

The residents participating in the five workshops we organized generously shared their experiences of living their everyday lives in Vallastaden. In this section, the focus is on the tinkering, caring, and sharing that goes into life in Vallastaden. Several participants talked with warmth about the feeling of living in a small village in Vallastaden. All participants said that they feel at home in Vallastaden and that they appreciate the diversity of houses and the area around the stream.

The workshop started with a few introductory questions and we then asked the participants to draw a map, in any way that suited them, of "their" Vallastaden. We then discussed the maps and asked what places mattered the most to them, what places they used and whether there were any places that they avoided. We also asked them to draw where their heart lay in Vallastaden.

\section{Nature as place for interactions}

A recurring theme in the workshops is the small stream which runs through Vallastaden. The stream has many uses, for example as a place for recreation. It can also be used as a source of weather information, as Karin ${ }^{3}$ and her family use it. Karin talks about her map over Vallastaden:

... The most important places are the places along the stream. Both for me and my children. We walk along the paths and the children play in the stream. We even use the stream to see if it's raining from our apartment if it doesn't show otherwise. You can see on the surface of the stream if it's raining. [...]. I walk two dogs sometimes and that gives me a chance to walk around the stream, I really enjoy that!

The carefully planned stream enables self-care through the beauty of nature, allowing space for children to play and for dogs to be walked. The path along the stream can create engagement and relations. The stream is furthermore used to tell if it is raining outside. Karin's apartment faces the stream and light rain showers can be hard to spot just from watching the windows of the apartment. Instead the stream offers information on the best way for her to dress her children, which makes her day easier. Once again, the stream contributes to Karin's ability to provide care for her children.
All participants in the workshop mentioned the stream as important and it is placed at the centre of most of the maps (see for example picture 1). It facilitates both a care for the self but also a place for meeting (a neatly ordered version of) nature. For example, one participant says:

Richard: [...] There are two paths that I often walk to the parking garage. One takes more time, but it passes more of the stream and I like to go by the stream. It's a bit exciting to see how it flows and how high the water reaches, like now it is really high! I like to look at the birds around the stream, the stream is really an artery.

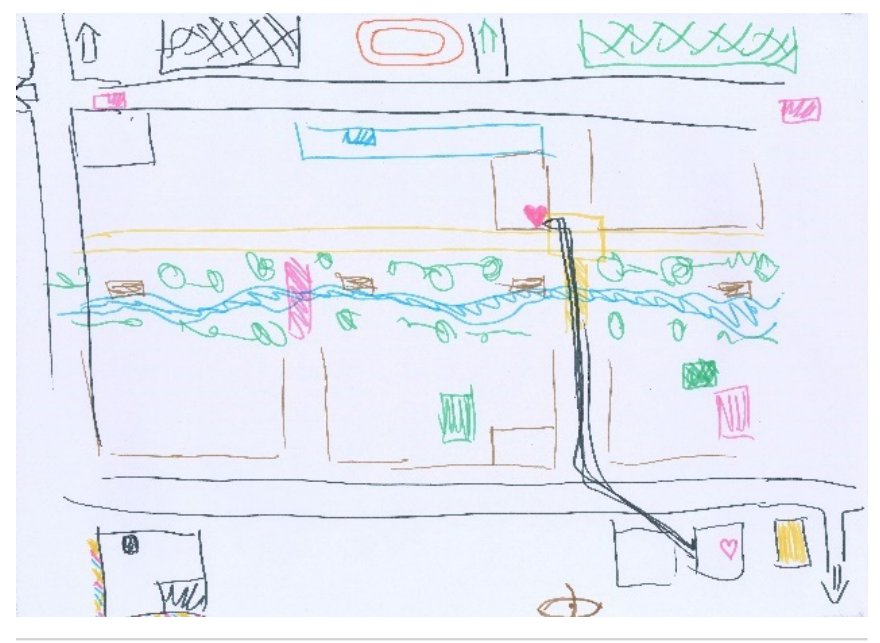

Picture 7 .

While the documents created in planning Vallastaden focuses on meeting places for people, the respondents in the workshops emphasize places where they meet nature. Animals living in the surroundings play an important role for many of the participants in the workshops. On the outskirts of Vallastaden, a field with sheep is painted into several of the maps. "I like the sounds they make", one of the participants reports. In the summer they sometimes walk through the sheep pasture and engage with the sheep. The sheep provide a valued nature experience and through them the participants say that they feel that they live closer to nature.

The stream is an important artery and the sheep create everyday excitement and builds relationships with nonhuman actors. Green areas are enacted as an important part of the social sustainability of the city district, both in the planning documents and by the residents - but in different ways. In the documents, the green areas are enacted as winter gardens and while the stream is important, it most often functions as a place for meeting other human actors. The more unruly nature experiences, such as walking through the sheep pasture, are seldom mentioned in the documents, while they

3 In this chapter, the participants will appear with changed names in order to ensure their privacy. 


\section{N}

NORDIC JOURNAL

of Science and Technology Studies

are more frequent in the stories by the respondents. Furthermore, the self-care opportunities that are built into Vallastaden enacts one version of what residents are supposed to enjoy. There is a lack of other types of community areas, such as a basketball court. Camilla, one of the participants in the workshop, confesses that she and her friends sometimes sneak into the school yard to use the basketball court even if she is not sure if it is allowed. The social sustainable version of activities enacted in the built environment in Vallastaden is one of calm enjoyment of nature rather than a fun ball game with friends.

\section{Caring in virtual space}

While the efforts of making place for meetings are central in the planning documents, they have not resulted in the respondents talking more with unknown people in Vallastaden than they did around their previous homes. Even so, they talk about having a feeling of more engagement in Vallastaden. This is shown in the Facebook group for residents in Vallastaden, Karin says, where she feels that she connects with people she otherwise would not have talked to.

Karin: Facebook is also an important meeting place for me. Since a lot of people moved into the area at the same time, it was easy to create new connections on Facebook.

While Karin's map of Vallastaden is centred on the stream she also draws a space for Facebook (picture 2).

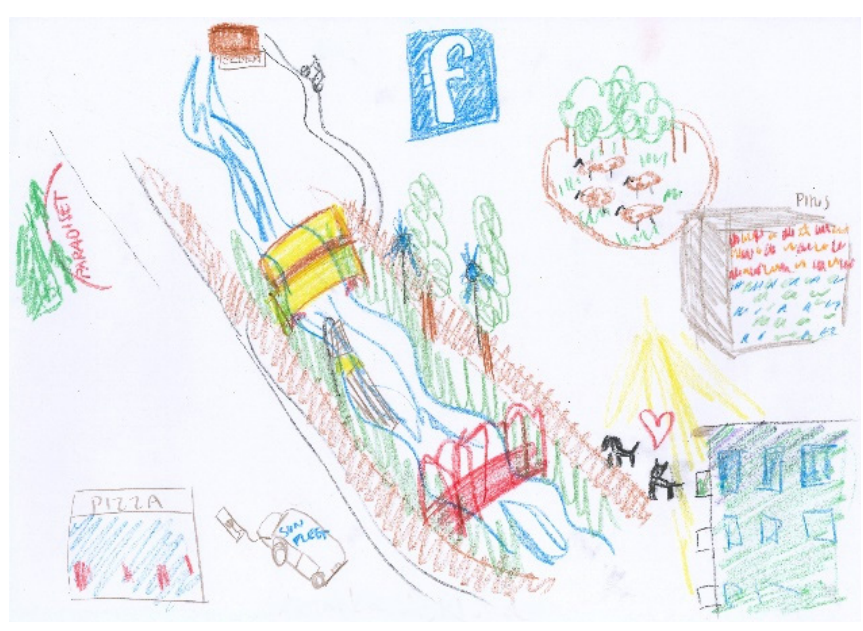

Picture 2.

The Facebook group was started by some residents in Vallastaden and Karin is one of the moderators. Several participants in the other workshops mention interactions in the Facebook groups. They receive local news, share things they no longer need, and find new connections with people living in Vallastaden. Thus, despite the care the urban planners have put care into arranging meeting places in Vallastaden, the residents told us that it is easier to seek connection with other residents in Vallastaden in virtual space than in person. Latour writes that space-time can be folded through technology (Latour, 1994) and thus, connections over the internet can fold the spatial space and create close connections over geographical distances. Even though the geographical distances are small in Vallastaden, Facebook is sometimes needed to close the gaps between the residents. Since Facebook facilitates connections and relationships, it can thus become a careful place.

However, many discussions on the social media site stir negative emotions. There are often pictures of garbage lying on the ground beneath the (often non-functional) garbage disposal system. Some of the participants in the workshop say that they get stressed over these pictures that keep being posted. There are tensions between different matters of care that are present in the Facebook group, where some people try to handle, or share the burden of, the garbage problem, while others feel that the problem is pushed on them. On Facebook, feelings are given space and residents can express their frustration. This suggests that a space for negative emotions, like stress, could be generative in the way that it allows space for feelings which can create connections between people who share the same issues. Care is not always enacted with good feelings, instead we are urged to stay with the troubles of care (Lindén 2016) and unsettling care (Murphy, 2015). The residents tinker with what tools are available to them to handle the everyday problem with garbage, an overflow of things, or a lack of connection. Facebook becomes a space where this multifaceted care can take place.

\section{Cars as trouble}

Richard: Something that bothers me is the noise from the traffic. Sometimes it is really loud... [...] and we don't like it when people use the bus lane in their cars! Then we get really pissed off! "laughs"

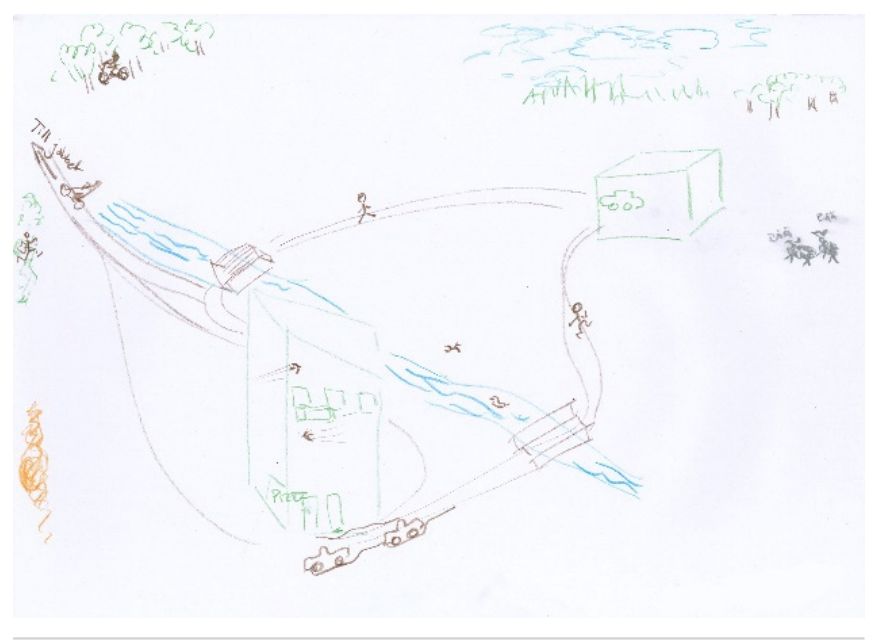

Picture 3.

The planning behind Vallastaden turned it into a city district in favour of accessibility and thus ascribed to a narrative where the car still holds a central role in our everyday life. For Richard, the closeness to nature is more important than having a car close by, 
even though he drives a car to work sometimes and cars are central in his map of Vallastaden (picture 3). A few of the other participants owned a car and several of the residents used the carpool they had to pay for as residents in Vallastaden. The car friendliness of Vallastaden brought up in the workshop has different aspects. Besides the noise and the speeding cars, some of the participants think that one of the main roads creates a divide between the houses and the Paradiset park. Even though the park is situated in connection to the houses, it feels cut off by the large road.

Furthermore, the electric cars which are allowed to park on the paths along the river were not appreciated by the respondents. Some expressed disappointment in the lack of car-free space, which was not what they had expected before moving to Vallastaden. In addition, one resident had a strong dislike of the car parks located on the outskirts of Vallastaden. The car parks are covered with solar panels and are the first thing you see when entering Vallastaden from the main road. With their energy efficiency and carpool, the car parks are part of the agenda to care for the environment. Even so, they are not appreciated by some. "It's like putting lipstick on a pig!", one participant said. He also painted death skulls on the car parks to emphasize his dislike of them (picture 4). Once he also saw snakes in there which, in contrast to the sheep, did not make him appreciate the place. One negative remark about the cars only being allowed to drive on some roads came from one resident, who complained about the hassle of moving when it is so complicated to reach her house by car. Otherwise, the presence of cars is one argument which the participants took up as a sign of the urban planning seeming to be uncaring about the ecological environment. They wanted more car-free space, partly referring to the sustainability agenda which they attributed to the vision of Vallastaden, and partly as their own appreciation of their homely environment.

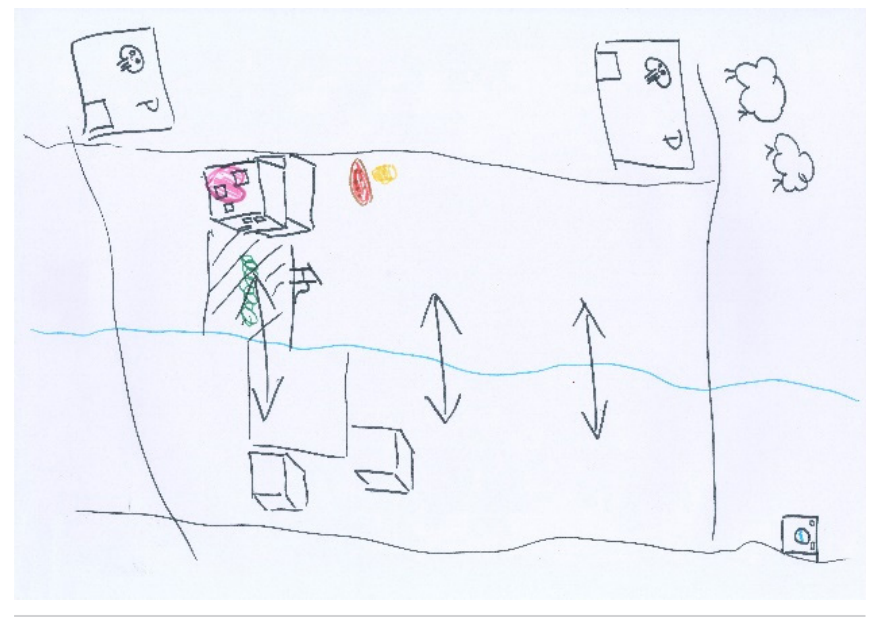

Picture 4.

Cars and their connected technologies belong to a narrative which troubles the care put into planning the city district. Analysing the troubles that come with care means holding on to the complex ethico-politics involved in matters of care (Lindén, 2016). Cars are made into trouble by the residents, who argue that cars are not part of the vision for a future city district. Cars are enacted differently by the residents and by the urban planners, making them both into care enablers (c.f. Eidenskog, 2015) and care trouble. In the planning process, cars were used to care for the environment and create a careful place, while the residents view cars as trouble. The workshop participants' understanding of what a social sustainable city district should care for stands in contrast with the planners', making the care put in the planning seem somewhat uncaring. Thus, cars cannot coexist with a careful place for the residents since they create strong dislike for place (the car park), annoying disturbances, and a feeling of uncaring planning.

\section{Creating a careful place - for whom?}

The manifold facets of a careful place are shown in the caring attachment from the start of the Vallastaden project to the disruptive everyday complexity of the lives in the built environment. Staying with the troubles of care and focusing on what is excluded as a consequence of this care, I have opened up the social sustainability agenda of Vallastaden, bringing what is made absent to the centre. Drawing attention to "neglected things" (Puig de la Bellacasa, 2012) in this case helps reimagine what is important for occasions to be caring and what is excluded in the vision of a social sustainable world. Some actors have a place in this vision, but the tinkering required to make space for them is done at the expense of others. Thinking about place with care requires attention to the neglected matters as well as to the matters of care that survive the toll of time and the planning processes. What was made absent in the documents in relation to the care for the environment was the presence of the great crested newts' home and the citizens' request for a car free city district. The tinkering required to make these matters of care absent involved a compensation in the living conditions for the newts and a tinkering with the concept of the future transport system. Instead of making cars absent, some cars got a prominent place at the streams together with their charging stations, all in the name of the future transport system. The translation done in the documents are without apparent tensions, but even so, cars are troublesome in the everyday life. Aversion against the carparks, irritation over fast-driving cars, and the feeling of a lack of care for the environment are some of the tensions that cars bring up in the everyday life. The care for the environment through cars is not translated from the documents to the experiences of the workshop participants. 
Care is not without frictions, which is made apparent in relation to some of the themes in the care practices in Vallastaden. Like how patients had to pass a threshold of criteria to get access to care in Latimer's research in healthcare (Latimer, 2018), some homes, such as the newts' or the low-income homes, did not pass the threshold to fit in the vision of the future city district. The politics of the threshold includes the social processes, materialities, and governing technologies which are aligned to decide what matters that pass as acceptable for the specific situation (Latimer, 2018). This assemblage of heterogenous actors that defends the threshold for the sustainable city district in Vallastaden includes urban planners, planning documents, political decisions inscribed in policies, vision boards from architects, and ordered versions of citizen engagement and nature. The voice of the citizens is present in the planning documents, albeit filtered by the urban planners. Nature is represented by spokespersons (such as the biologists investigating the newts' habitats) and its representation and presence in Vallastaden comes in ordered forms (such as in structured reports or the well-organized park Paradiset). The constitution of the assemblage ordering the sustainable city district threshold is significant for what matters of care that will pass it. The focus on the neglected matters of care and assemblage of actors creating the thresholds for the social sustainable city district can contribute to the unsettling of care, an "purposeful undoing and troubling of particular arrangements so that they might be acknowledged and remade in better, less violent, more livable ways" (Murphy, 2015, p. 722). In troubling the assemblage behind the planning of Vallastaden, nature's inability to communicate its will and desires through spokespersons raises questions on the assemblage's symmetry. Metzger (2016) urges urban planners to utilize a more-than-human planning sensibility with a broader methodological scope to avoid relying on spokespersons. In line with this, Schrader (2015), for example, argues that learning about bugs by drawing them can generate an affective and epistemic intimacy, a form of "passionate detachment", which enables a new kind of spatial temporality and a different kind of care. Utilising aesthetics or other unconventional methods would broaden the ensemble of methods and thus engendering co-affectation between humans and non-humans that does not only work with human language as its medium (Metzger, 2016). Staying with the troubles of careful place could be a way to "cultivate torment" (Metzger, 2016) in city planning and open up for new ways to organize the assemblage enacting the thresholds for what matters of care that are included in the vision for inclusive city planning for the city district of tomorrow.

Unsettling care for Vallastaden has shown the need for critical engagement in the assemblage that enacts the thresholds of the social sustainable city district of tomorrow. Furthermore, it has shown how careful place is not only created through careful planning or through spatial space where one can practice warm care for loved ones. The urban planning process focused on creating meeting places, such as the Felleshus and green areas. However, one important meeting place was created by the residents. On the Vallastaden Facebook group, the people of Vallastaden can give out things they do not need or inform each other of news. It is also a space for complaints and heated discussions. Facebook is a space for frustration and negative feelings as well as a way to make connections over spatial distances. Care is not exclusively linked with positive feelings (Martin et al., 2015; Murphy, 2015; Lindén, 2016), instead generative care can come from tension and unease. Sharing problems can be a way to heal and to create caring connections and the Vallastaden Facebook group contributes to making issues visible and allowing for connections. Careful places can have many shapes and can be an outcome from careful planning, from meetings with nature and from citizen engagement, as shown in Vallastaden.

Thinking with care about place urges us to take an open mind, rethinking place not only as a spatial feature but also as ethicopolitical, multifaceted, and heterogenic while bringing together space, humans, technology, and non-humans. Caring comes with consequences and when careful space is enacted as a role-model, socially sustainable future city district, high stakes are involved. A version of diversity as a broad socio-economic demography was made absent in the planning documents over time. There was an elaborate tinkering involved in the translation from a version of diversity of people to a version of diversity in architecture and apartment sizes. The creativity of a diverse cityscape and value of flexible housing enabled a version of diversity in which some ethicopolitical issues were made absent. Thus, when social sustainability in the built environment is turned into diversity of architecture some homes are rendered impossible. By showing how this worldmaking cuts off some homes that do not fit in, we can recognize the unfairness in the efforts in designing Vallastaden. Puig de la Bellacasa (2011) points out "To represent matters of care is an aesthetic and political move in the way of re-presenting things that problematizes the neglect of caring relationalities in an assemblage." (Puig de la Bellacasa, 2011, p. 94). Thinking with matters of care has in relation to careful place enabled concern for exclusions and critiques of power dynamics in stratified worlds. A home in Vallastaden has several embedded layers of political and ethical standpoints. Even though there are several careful places in Vallastaden, the care is available only to some.

Looking back on Vallastaden with inspiration from Metzger (2014) we can ask: What can be done here? What can become here? And at what price? These questions urge us to focus on care which in this context offers a perspective seldom discussed in the political debate on social sustainability and the future city district. This analysis shows how tracing what matters of care pass the threshold to the sustainable city district and what matters are marginalized as a consequence of this care. In this, unsettling of care complicates the hegemonial planning narratives and brings back neglected things into the frame. The planning process for a role model city enacts a version of diversity which 
has consequences for whom the city is built. The matters of care which were allowed space in the planning documents invite some homes while they exclude others. Since Vallastaden is marketed as a role model for future city planning, it is vital that the ethico-political decisions and care put into the planning and enactment of the city district are brought into focus and hence opening up for more radical visions of what a sustainable world might look like.

\section{Acknowledgements}

Thank you to Doris Lydahl and Lisa Lindén for their editorial guidance, as well as to the two anonymous reviewers for their very insightful comments on the manuscript. I am also grateful to the organizers and participants of the Care in STS: objects, transformations and politics panel held at Tampere University in 2019, as well as the research group STRIPE at Linköping University, for their help in improving this article. Research for this article was conducted by the author in collaboration with Wiktoria Glad. Thank you Wiktoria for great collaboration! The work was supported by a grant from the Swedish research institute for sustainable development (FORMAS).

\section{Author biography}

Maria Eidenskog is a Research Fellow at the Department of Thematic Studies - Technology and Social Change at Linköping University. She is an interdisciplinary social scientist with research interests that include energy efficiency, digitalization, and social sustainability in relation to the built environment. Her work explores matters of care in the enactment of sustainability through a focus on the interplay between place, materiality, human and non-human actors, and digital technologies.

\section{References}

Aibar, E., \& Bijker, E. (1997). Constructing a city: The Cerdà plan for the extension of Barcelona. Science, Technology, \& Human Values, 22(7), 3-30. https://doi.org/10.1177/016224399702200101

Alvin, Å. (2018). LISTA: De får bygga i Vallastaden [LIST: They get to build in Vallastaden]. Corren.

https://www.corren.se/nyheter/linkoping/lista-de-far-bygga-ivallastaden-om5540783.aspx

Arnett, $\mathrm{H}$. (2017). The challenges in quantifying social sustainability at a neighborhood level. Cities \& Health, 1(2), 139-140. https://doi.org/10.1080/23748834.2018.1460104

Baffoe, G., \& Mutisya, E. (2015). Social sustainability: A review of indicators and empirical application. Environmental Management and Sustainable Development, 4(2), 242-262.

https://doi.org/10.5296/emsd.v4i2.8399

Bouzarovski, S. (2015). Retrofitting the city: Residential flexibility, resilience and the built environment. Bloomsbury Publishing.

Callon, M. (1986). Some elements of a sociology of translation; Domestication of the scallops and the fishermen of St Brieuc Bay. In J. Law (Ed.), Power, action and belief. A new sociology of knowledge? (pp. 196-229). Routledge.

Denis, J. \& Pontille, D. (2015). Material ordering and the care of things. Science, Technology, \& Human Values, 40(3), 338-367. https://doi.org/10.1177/0162243914553129

Dyck, I. (2005). Feminist geography, the 'everyday', and local-global relations: Hidden spaces of place-making. Canadian Geographer/Le Géographe canadien, 49(3), 233-243.

https://doi.org/10.1717/j.0008-3658.2005.00092.x

Dyck, I., Kontos, P., Angus, J., \& McKeever, P. (2005). The home as a site for long-term care: Meanings and management of bodies and spaces. Health \& place, $17(2), 173-185$.

https://doi.org/10.1016/j.healthplace.2004.06.001

Eidenskog, M. (2015). Caring for Corporate Sustainability. (Publication No. 644) [Doctoral dissertation, Linköping University]. http://urn.kb.se/resolve?urn=urn:nbn:se:liu:diva-117098

Gad, C., \& Bruun Jensen, C. (2010). On the consequences of postANT. Science, Technology, \& Human Values, 35(1), 55-80. https://doi.org/10.1177/0162243908329567

Gould, P., \& White, R. (2004). Mental maps. Routledge. https://doi.org/10.4324/9780203111512

Harbers, H. (2010). Animal farm love stories. In A. Mol, I. Moser, \& J. Pols, (Eds.) Care in practice. On tinkering in clinics, homes and farms (pp. 141-70). Transcript Verlag. https://doi.org/10.14367/transcript.9783839414477

Hedin, K., Clark, E., Lundholm, E., \& Malmberg, G. (2012). Neoliberalization of housing in Sweden: Gentrification, filtering, and social polarization. Annals of the Association of American Geographers, 102(2), 443-463. https://doi.org/10.1080/00045608.2011.620508

Heuts, F. \& A. Mol, 2013. What is a good tomato? A case of valuing in practice. Valuation Studies, 1(2), 125-146.

https://doi.org/10.3384/vs.2001-5992.1372125

Jensen, T., \& Sandström, J. (2019). Organizing rocks: Actor-network theory and space. Organization, 27(5), 701-716. https://doi.org/10.1177/1350508419842715

Kurath, M., Marskamp, M., Paulos, J., \& Ruegg, J. (2018). Relational planning: Tracing artefacts, agency and practices. Palgrave Macmillan.

Latimer, J. (2018). Afterword: Materialities, care, 'ordinary affects', power and politics. Sociology of Health \& Illness, 4O(2), 379-391. 
https://doi.org/10.1171/1467-9566.12678

Law, J. (2004). After Method - Mess in social science research. Routledge. https://doi.org/10.4324/9780203481141

Law, J. (2009) Actor-Network Theory and material semiotics. In B. Turner (Ed.), The New Blackwell Companion to Social Theory (pp. 141-158). Blackwell https://doi.org/10.1002/9781444304992.ch7

Law, J. (2010). Care and killing: Tensions in veterinary practice. In A. Mol, I. Moser, \& J. Pols (Eds.), Care in practice. On tinkering in clinics, homes and farms (pp. 141-70). Transcript Verlag. https://doi.org/10.14361/transcript.9783839414477

Lindén, L. (2016). Communicating care: The contradictions of HPV vaccination campaigns, Arkiv förlag \& tidskrift. https://doi.org/10.3384/diss.diva-127638

Linköping University. (2013). Fridlyst hyresgäst flyttar ut [Protected tenant is moving]. https://insidan.liu.se/nyhetsarkiv/7.485858?l=sv

Lundin, P. (2008). Bilsamhället: ideologi, expertis och regelskapande i efterkrigstidens Sverige [The car society: ideology, expertise and rulemaking in post-war Sweden,]. Stockholmia förlag.

Malmgren, J. (2011) Större vattensalamander -Triturus cristatus [The great crested newt -Triturus cristatus]. Swedish Environmental Protection Agency.

https://www.naturvardsverket.se/Om-Naturvardsverket/ Publikationer/ISBN/5600/91-620-5636-0/

Martin, A., Myers, N., \& Viseu, A. (2015). The politics of care in technoscience. Social Studies of Science, 45(5), 625-641. https://doi.org/10.1177/0306312715602073

Metzger, J. (2014). Spatial planning and/as caring for more-thanhuman place. Environment and Planning, 46(5), 1001-1011. https://doi.org/10.1068/a140086c

Metzger, J. (2016). Cultivating torment: The cosmopolitics of morethan-human urban planning. City, 20(4), 581-601. https://doi.org/10.1080/13604813.2016.1193997

Mol, A. (2002). The Body Multiple: Ontology in Medical Practice. Duke University Press. https://doi.org/10.1017/S174585520722558X

Mol, A., Moser, I., \& Pols, J. (Eds.). (2010). Care in Practice. On Tinkering in
Clinics, Homes and Farms. Transcript Verlag.

https://doi.org/10.14367/transcript.9783839414477

Moser, I., \& Law, J. (2006). Fluids or flows? Information and qualculation in medical practice. Information Technology \& People, 19(1), 55-73. https://doi.org/10.1108/09593840610649961

Murphy, M. (2015). Unsettling care: Troubling transnational itineraries of care in feminist health practices. Social Studies of Science, 45(5), 717-737. https://doi.org/10.1177\%2F0306312715589136

Okidoki. (2020). Vallastaden. https://www.okidokiarkitekter.se/vallastaden/

Osóch, B., \& Czaplińska, A. (2019). City image based on mental maps-the case study of Szczecin (Poland). Miscellanea Geographica, 23(2), 111-119. https://sciendo.com/article/10.2478/mgrsd-2019-0016

Palm, J., \& Wihlborg, E. (2013). Vallastaden växer fram: policy och planering för en ny stadsdel [Vallastaden is emerging: Policy and planning for a new district], Linköping University Electronic Press.

http://urn.kb.se/resolve?urn=urn:nbn:se:liu:diva-90440

Puig de la Bellacasa, M. (2011). Matters of care in technoscience: Assembling neglected things. Social Studies of Science, 41(1), 85-106. https://doi.org/10.1177/0306312710380301

Puig de la Bellacasa, M. (2012). 'Nothing comes without its world': Thinking with care. The Sociological Review, 60(2), 197-216. https://doi.org/10.1171/j.1467-954X.2012.02070.X

Puig de la Bellacasa, M. (2015). Making time for soil: Technoscientific futurity and the pace of care. Social Studies of Science, 45(5), 691-716. https://doi.org/10.1177/0306312715599851

Puig de la Bellacasa, M. (2017). Matters of care: Speculative ethics in more than human worlds. University of Minnesota Press.

Saldana, J.M. (2009). The Coding Manual for Qualitative Researchers. SAGE Publications Ltd.

Schrader, A. (2015). Abyssal intimacies and temporalities of care: How (not) to care about deformed leaf bugs in the aftermath of Chernobyl. Social Studies of Science, 45(5), 665-690. https://doi.org/10.1177/0306312715603249

Till, J., \& Schneider, T. (2005). Flexible housing: The means to the end. ARQ: architectural research quarterly, 9(3-4), 287-296. https://doi.org/10.1017/S1359135505000345 